strength. In a year when the University profited from a significant enrollment increase, our budget received double the highest increase received by the colleges of the University. It also was the largest increase in funding received by the library in its recent history. Our visibility throughout the year was enhanced by continued media, especially local television, coverage of our "Year of the Reader" programs. Secondly, our faculty and staff gained considerable expertise in developing and sustaining promotional activities.

Academic libraries should look at National Library Week as an excellent opportunity to increase library awareness on the campus. While this could certainly be done through various promotions at other times of the year, I think the academic library can benefit from:
- the national attention being centered on libraries that week;

- from the materials and other support provided by ALA in its efforts to promote National Library Week;

- from the activities simultaneously occurring that week in public and school libraries;

- and finally, from the possibility of joining with public and school librarians to cooperatively develop National Library Week programs benefiting all kinds of libraries.

Editor's note: This is a revision of a presentation given at the National Library Week Workshop, ALA Midwinter Meeting, San Antonio, January 11,1988

\title{
A visit to the
}

\section{National Library of New Zealand}

\author{
By Jane Kemp \\ Circulation/Reference Librarian \\ Luther College
}

\section{Less than a year old, New Zealand's library is a national treasure.}

D uring a trip to New Zealand for the holidays I had planned to visit several academic libraries in the various cities in which I would be staying. Lydia Klimovitch, general secretary of the New Zealand Library Association, had suggested a range of libraries to visit in the course of our correspondence over the previous months. However, during our Air New Zealand flight, a program was aired over the plane's sound system in which deputy librarian Adam Smith of the National Library of New Zealand was interviewed. His responses in the interview made this newly opened national library sound so interesting and impressive that I resolved to alter my travel arrangements so as to be in Wellington for a day to visit that facility.

Although the National Library of New Zealand was established by Act of Parliament in 1965, it was not completed until July 1987. At the site selected for the new library, only a hole in the ground remained for many years for various reasons- 


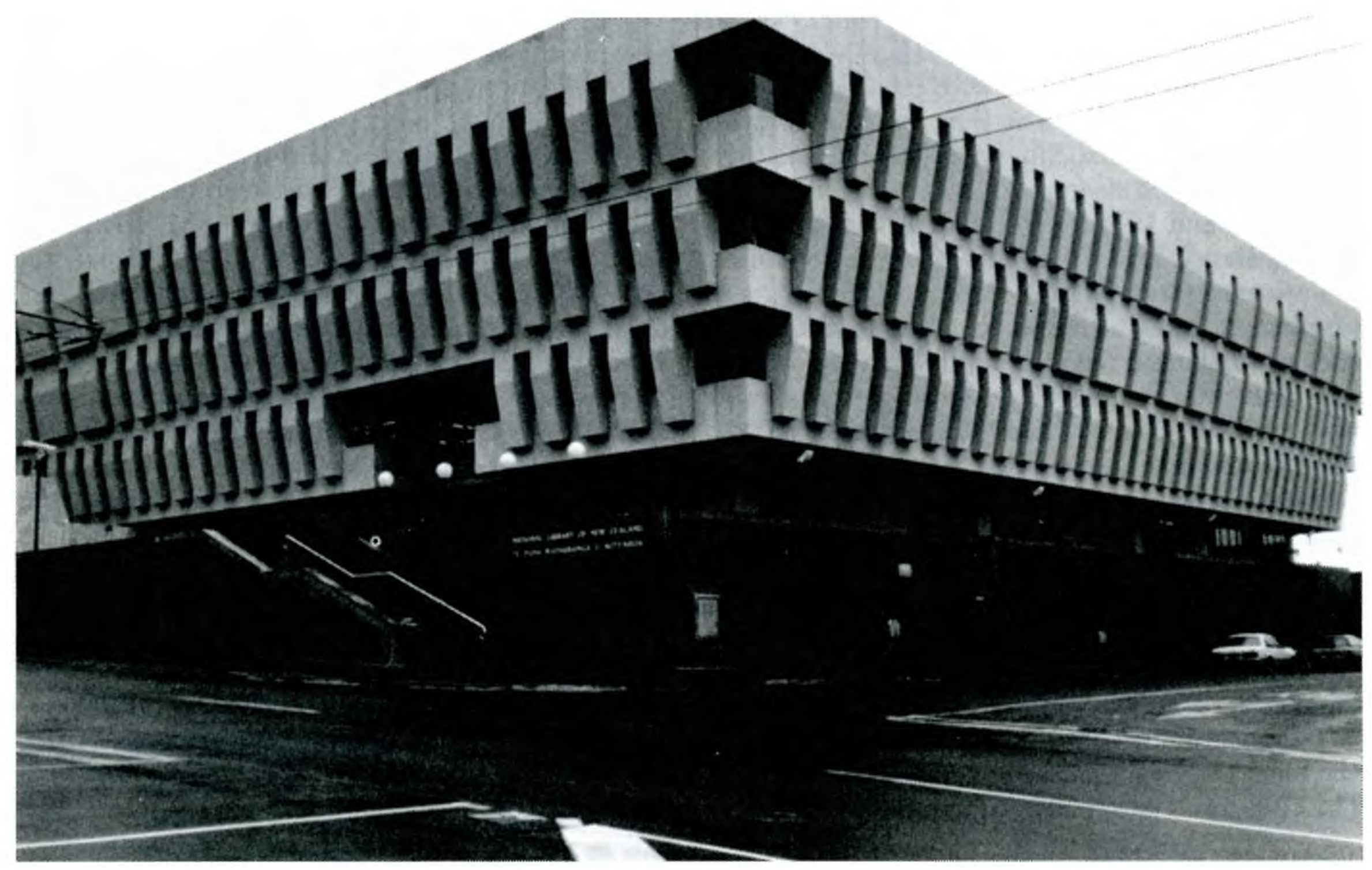

The National Library of New Zealand.

strikes of construction workers and changes in government and fund allocations were some of the jus tifications given for the slowness of construction. However, when it opened last year, the facility brought three existing libraries together under one roof. The Alexander Turnbull Library, a private library given to the nation in 1918, housed important volumes of New Zealand material, newspapers, manuscripts, paintings, and prints. The National Library Service, begun in 1938 to provide books for people in country areas, and the General Assembly Library, which had served the government of New Zealand since the 1860s and was located in the heart of Wellington in the midst of the government complex, were combined.

The responsibilities of the National Library were also laid out in the 1965 Act: to collect, preserve, and make available recorded knowledge, particularly that relating to New Zealand; to supplement and further the work of other libraries in New Zealand; and to enrich the cultural and economic life of New Zealand while enriching its cultural interchanges with other nations. The maori name of the National Library, Te Puna Matauranga o Aotearoa, the well or spring of knowledge, symbolizes these functions.

The library building itself was designed by the Ministry of Works and Development and finally built over a period of 13 years at a cost of $\$ N Z 50$ million. It is climate controlled and protected from fire with a system that "floods" an area with inert gas to smother fire. Most of the books are stored on the lower floors (there are six levels) and are deliv- .ered on a computer-controlled monorail delivery system that snakes its way through the building. The system runs both horizontally and vertically at about 5 miles per hour.

Currently the collection consists of 5 million books, microfiche, and single-issue journals that were collected via purchase, donations, and bequests, and legal deposit. The library has copies of almost everything published in New Zealand and so can readily provide copyright evidence if needed. In addition, an extensive sound and music collection of old records, early recordings of speeches on subjects such as the royal visit in 1953, and the New Zealand oral history archive are being enlarged. A paper preservation program has also been instituted to conserve early papers and books.

The staff of 320 in Wellington plus additional staff in three regional centers and 13 district centers are directed by the National Librarian. This person in turn is responsible to the Minister of Education. The library is divided into six divisions: Collections Management, Reference and Interlibrary Loan, Corporate Services, New Zealand Bibliographic Network (NZBN), Regional Services, and the Turnbull Library.

The NZBN was of particular interest since it is a computerized catalog and information retrieval network for the nation established in 1982. Designed in the U.S. by the Boeing Aircraft Company for the Washington State Library Network, the library purchased a license to use the system. It contains records of books and other materials held at the National Library as well as other major public, 
university, government department, or private company libraries in New Zealand. Over 500,000 records per year are added to the network. The NZBN is regularly updated with records from the U.S. Library of Congress and the national libraries of Canada, Australia, Singapore, and Great Britain. Currently 54 members pay on a full membership basis, and 106 casual members dial in on the New Zealand Post Office packet switch network.

Future emphases for the National Library are to supplement its School Library Service and reference services to the nation's public libraries with direct collection management assistance. Mail services to rural users are also being augmented as a result of a review that studied the needs of families without library access. In addition, increased emphasis is also being given to a program of depositing collections of books in rural area school/community libraries. SATIS (Scientific and Technical Information Service), a nationwide information service offered for industry and business, is also being expanded.

The goal of the National Library to be the memory bank of New Zealand is certainly being met. The Children's Collections of the library include a comprehensive range of books for children and young adults written in New Zealand, Australia, Great Britain, and North America. The emphasis on publications printed in New Zealand and books that would have been read by children living in New Zealand from colonization (ca. 1800) to 1940, makes this a valuable resource for researchers. The Pictorial Collections of photographs, paintings, drawings, prints, maps, charts, and printed ephemera (posters, programs, greeting cards, etc.) encompass New Zealand and the Pacific from early times. In addition, the Sound and Music Centre provides collections in all media including scores from the Radio New Zealand library of orchestral and chamber music, collections of New Zealand music, and materials from the Oral History Archive.

Browsing members of the public, researchers, genealogists, students, and tourists are all encouraged to use the facilities of this new National Library. Featuring the library on the "all about New Zealand" sound service channel of New Zealand's largest air carrier gives some indication of the stature of this library to the people of New Zealand.

\section{Nine university libraries attack journal inflation}

Directors and collection development officers from nine university libraries met January 28 in Lawrence, Kansas, to plan ways to confront the devastating impact runaway journal and other serials prices are having on the abilities of libraries across the country to buy needed materials for faculty and students.

Average inflation rates for serials of $12 \%$ to $20 \%$ were reported, depending on the mix of foreign and domestic subscriptions received by the individual libraries. Most alarming is the fact that these rates have been accelerating over the past few years. The continuing high increase in prices has already led to major subscription cuts and many campuses are anticipating even larger reductions over the next few months. The cuts are coming when most of the libraries are expected to support increased research as the basis for greater economic development and as their state governments strive to attract new industry.

All of those present predicted that inflation will continue at current rates for at least the next few years. The major culprit is a weakened dollar measured against European currencies, a serious problem for universities where research requires heavy reliance on foreign journals. Another factor is the practice of price discrimination that many Western European publishers apply when selling their journals in North America - U.S. libraries pay more for a serial than their European counterparts. Also contributing to the problem is the ever increasing number of new journals being published in support of developing areas of knowledge. Whatever the causes of price increases all agreed that continued subscription cuts are inevitable and that cooperation among university libraries is essential.

As a result of the meeting, a common database will be developed listing all serial titles priced at more than $\$ 200$. Each library will then indicate the titles it owns. The ultimate hope being that as further subscription cuts are made, one copy of each important title will be maintained by a minimum of one library in the region. The next step will seek improved document delivery among the nine institutions. Outside funding may be sought for the development of electronic means of document transfer. Finally, the participants agreed to share information on the overall problem and to cooperate on efforts to inform local campus constituencies and funding agencies on the seriousness of the issue.

Institutions represented at the Lawrence meeting were Iowa State University, the University of Missouri-Columbia, Kansas State University, the University of Kansas, the University of NebraskaLincoln, Oklahoma State University, the University of Colorado, Colorado State University, and the University of Wyoming. The University of Oklahoma also plans to participate in the effort. The database development project is being coordinated by the University of Nebraska-Lincoln. 


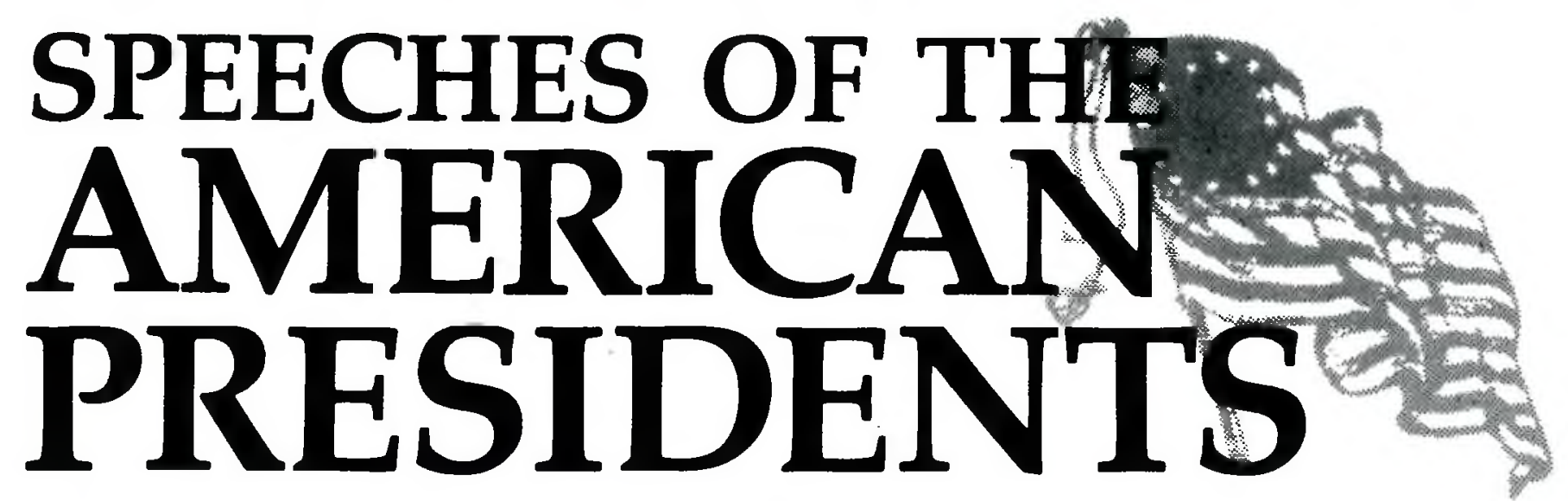

Edited by Janet Podell and Steven Anzovin. Introduction by John Little, Associate Editor, Woodrow Wilson Papers 850pp. approx. 1988. ISBN 0-8242-0761-0 $\$ 60$ U.S. and Canada, $\$ 70$ other countries.

\section{Major Speeches by} 40 U.S. Presidents

Since the birth of the Republic, the great issues of American history-war, peace, slavery, suffrage, taxes, and tradehave been the subjects of speeches by U.S. Presidents. Now, for the first time in a single volume, the most memorable and important addresses of each of the 40 Presidents have been gathered together in Speeches of the American Presidents.

\section{The Presidents Speak- And History is Made}

Covering the decisive events of each administration, Speeches of the American Presidents contains both landmark and lesser-known addresses, among them:

Adams" "The Nature of the Federal Government:"

- Harding's "The Rights of Black Citizens."

- Lincoln's "Gettysburg Address."

-JFK's "Ich Bin ein Berliner" speech.

- FDR's "Nothing to Fear but Fear Itself" speech.

- Eisenhower's "Don't Join the Bookburners" address.

- Reagan's "Evil Empire" and "Star Wars" speeches.

"Politics is mostly talk, and this volume brings together many of the consequential and elevating moments of presidential rhetoric."

-George F. Will

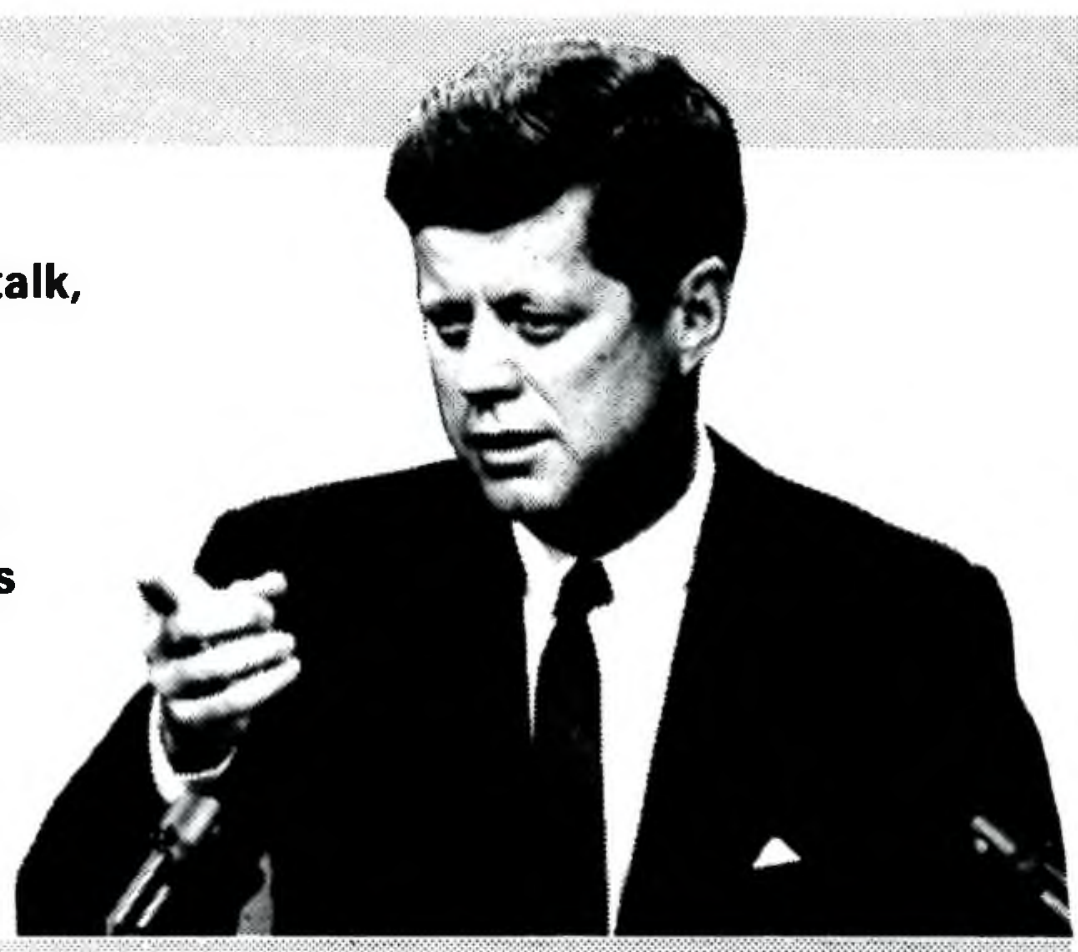

\section{A Reference Source for Everybody}

With an extensive Subject Index that highlights the recurring themes of Presidential addresses, Speeches of the American Presidents devotes a chapter to each President, and contains:

Four to ten speeches, most in full.

- An introduction describing the circumstances surrounding the composition and delivery of each speech.

- An account of each President's rise to power and the key events of his administration.

- An introductory essay on the history of Presidential speechmaking.
To Order Call Toll-free 1-800-367-6770

In New York State call 1-800-462-6060;

in Canada call collect 212-588-8400

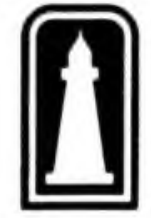

THE H.W. WILSON COMPANY

950 University Avenue Bronx, New York 10452 (212) 588-8400 


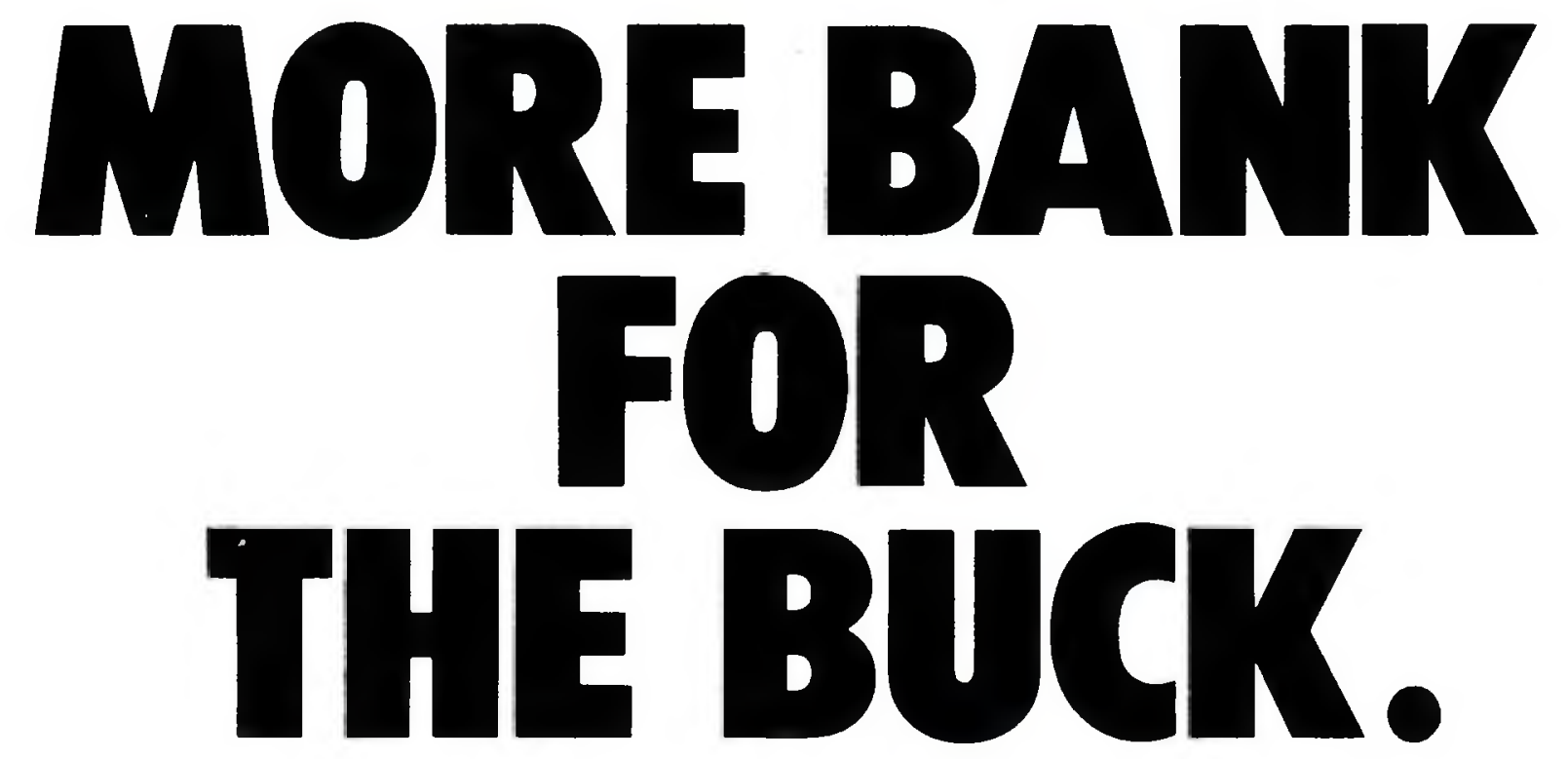

When they have questions about banks, do you have the answers?

Sheshunoff bank information is bona fide bank information. That's why

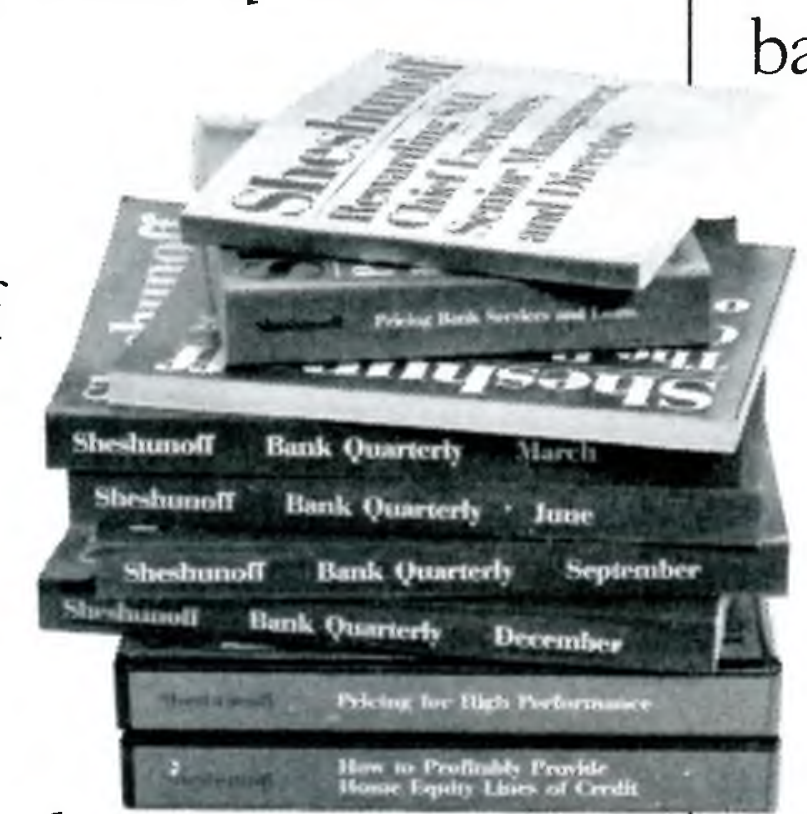
over 13,000 bankers use our books and reports.

You can get the bank data you need the way you want to use it. Complete with guides to how to use it.

You can have books that quickly analyze every bank in the country. Detailed analysis on all the banks in a particular state

or examine

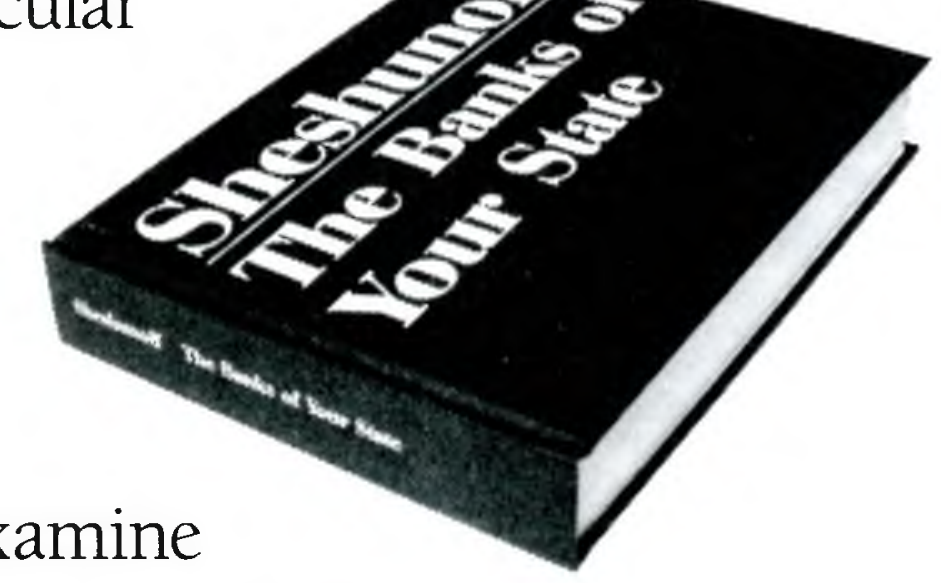

just one bank in as much detail as you want. And more.
You don't need to be a banker to use our information. Anyone who can compare numbers can find answers to their questions with our useful reference tools. And our industry surveys present easy-tofollow data from banks across the country.

No resource is more thorough, more accurate, or easier to use.

Our Customer Service Representatives will be happy to tell you more about our books, reports, and surveys.

You can even examine a book for 30 days without obligation. For more information, please call us at (512) 472-2244.

Sheshunoff \& Company, Inc.

One Texas Center 505 Barton Springs Road Austin, Texas 78704

\section{Sheshunoff \\ Aliph Pertornance Banking}

